\section{Iva Glišić}

The Australian National University

School of History

Research School of Social Sciences

ANU College of Arts \& Social Sciences

Canberra

Australia

\section{Tijana Vujošević}

University of British Columbia

School of Architecture and Landscape Architecture

Vancouver

Canada
UDC 821.163.41.02ZENITIZAM

doi 10.5937/ZbAkU2109029G

Original scientific paper

\title{
Zenitism and Orientalism
}

Abstract: Reflecting on the centenary of the birth of Zenitism, this essay examines how the movement engaged with stereotypes about the Slavic Orient, and in particular the discourse on Balkanism. The European orientalist reading of the Balkans became especially profound in years surrounding the World War I. Seeking to invert derogatory characterisations of the Balkan Peninsula, Zenitists would embark on a mission to „Balkanise Europe“ by presenting the artist from the East as a rejuvenating, revolutionary force emerging from a cultural tabula rasa. Zenitism sought to destabilise the dominant Orient-Occident discourse by establishing parallels between existing negative stereotypes of the Balkans and the aesthetic tropes of the European avantgarde. Specifically, Zenitists established the Balkan „Barbarogenius“ as the archetypal modernist primitive - precisely the figure conjured by the European intelligentsia as the saviour for its listless modern condition. In addition, the Zenitist movement established an analogy between the hallmark fragmentation of the Balkans and the cultural cacophony of the avant-garde. The political and aesthetic strategies of the movement, the authors assert, bear a striking similarity with those of the Black Atlantic, and its 'in-betweenness'-its ambition to straddle two opposing worlds. Organised around its eponymous journal Zenit, which was conceptualised as „the first Balkan journal in Europe and the first European journal in the Balkans," Zenitism employed European avant-garde aesthetic strategies while simultaneously rejecting European claims to cultural supremacy. For Yugoslav, Soviet, and Western European audiences, the journal had two parallel goals: the creative "Balkanisation" of Europe, and a commitment to dismantling Yugoslav „nesting orientalisms“ by fighting against the reproduction 
of negative stereotypes among the region's own inhabitants. Against a backdrop of European crisis and a global demand for a renewed emancipatory struggle, the ambition of Zenitism holds strong appeal today.

Key words: avant-garde, Zenitism, Yugoslavia, Orientalism, Balkanism.

\section{Zenitism and Orientalism}

In 2021 we observe the centenary of the birth of Zenitism - Yugoslavia's first avant-garde movement - which began with the February 1921 publication of the first issue of its eponymous journal, Zenit. In addition to having provided an important foundation for the young country's entry into international artistic circles, Zenitism is recognised by scholars as having assumed for itself an enormous challenge: that of dismantling centuries-long prejudices in order to position Eastern Europe - and the Balkans more precisely - as a constituent part of the European family. This anniversary provides an opportune moment to consider Zenitism through a genealogy of orientalism and Balkanism, and examine the movement's efforts to counter and subvert negative stereotypes of a geographic region and its inhabitants - many of which continue to define contemporary existence.

In critical theory, the notion of orientalism is inextricably linked to the work of Edward W. Said, whose ideas about the politics of colonialism were first presented in his seminal book Orientalism more than four decades ago (Said, 1979). ${ }^{1}$ In this groundbreaking work, Said famously proposed that the Orient is not merely a geographical fact but an ideological construct used to define the notion of the West by positioning the East as its Other, as its defining counterpart. The construction of the symbolic East, Said asserted, is imbricated with relationships of power and a discourse by which the East is culturally inferior and in need of enlightenment and rational governance. Orientalism includes the institutional practices of government, as well as science, scholarship, and the arts all of which serve to justify and reinforce hegemonic power. While Said primarily discusses the Western colonialist constructions of the Islamic world in Orientalism, he does also acknowledge other 'regional' studies and domains of expertise, such as those on Soviet Union or China, as belonging to the same category (Said, 1979: 17). He gives the example of the field of Russian studies as a fundamentally politicised subject matter, which at the same time involves the pretence of „suprapolitical objectivity“ as a strategy for positioning the West's reading of this space as ,impartial“" or normative (Said, 1979:

1 See also Edward W. Said.1993. Culture and Imperialism. London: Chatto \& Windus. On debates developed in connection with Said's work, see Robert J. C. Young. 2001. Postcolonialism: An Historical Introduction. Oxford: Blackwell Publishers. 
18). In this way, Said provides the foundation for expanding the Orientalist notion to a diverse range of narratives and practices based on the conceptual dialectic between the European and the non-European.

An intriguing elaboration of Said's theory can be seen in scholarship that establishes a connection between the notion of orientalism and the various discourses on Eastern Europe, and most prominently those perpetuating stereotypes about the Balkans as constitutive of both European and quasi-European identity. In her pioneering 1997 book Imagining the Balkans, Maria Todorova would demonstrate the centurieslong process through which the notion of the Balkans as an uncivilised, disorderly, violent, and irrational geographical and cultural domain was formed in the collective imagination. Many scholars have subsequently followed in Todorova's footsteps, examining the intellectual practices that gave rise to such perceptions of the Balkans, producing a Balkanist discourse especially through journalistic and „quasi-journalistic literary forms" such as travel writing, political essays, and academic journalism (Todorova, 2009: 19; Dix, 2015; Fleming, 2000; Hammond, 2004). In parallel, a range of scholars have attempted to position the constructs of the Balkans within the framework established by Said, while showing how „Balkanism“ presented a discrete body of knowledge and political practice (Bijelić and Savić, 2003; Hammond, 2007).

With the dissolution of socialist Yugoslavia in the early 1990s and the country's descent into civil war, the Balkanist discourse re-emerged with full force. Among other things, this provided impetus for a concerted study of the history and evolution of Balkanism, with scholars such as Milica Bakić-Hayden examining political narratives grounded in the Balkanist discourse that saturated the public domain as Yugoslavia was falling apart (Bakić-Hayden and Hayden, 1992; Bakić-Hayden, 1995; Bakić-Hayden, 2006). This line of investigation continues to hold significant political urgency today, in an era where belonging to Europe-proper is charted by the borders of the European Union (EU) and in which, as Rastko Močnik writes in reference to Slovenia, the distinction between membership in the enlightened and prosperous world means rejecting (or otherwise overcoming) Balkan identity and those stereotypical cultural markers that come with it (Močnik, 2003). ${ }^{2}$ In particular, the introduction of the 'Western Balkans' appellation over the past two decades has served to perpetuate the use of the Balkan label asa tool of stigmatisation and exclusion (Kølsto, 2016). While those countries in the south eastern quadrant of the continent that have achieved membership status within the EUno longer carry the burden of the Balkan descriptor, those lingering in the waiting room remain collectively labelled as the (Western) Balkans - an act that cements 'Europe' and 'the Balkans' as incompatible, and indeed mutually exclusive notions.

2 See also Stef Jansen, "Svakodnevni orijentalizam: Doživljaj 'Balkana'/'Evrope' u Beogradu i Zagrebu," Filozofija i društvo (Journal of the Belgrade Institute for Social Research and Philosophy) XVIII (2002): 33-71. 
As the one hundred year anniversary highlights, however, efforts to overcome this apparent incompatibility are not new. The first systematic critique of (and creative response to) the notion of Balkanism emerged in the aftermath of World War I, and was driven by those active in the creative circles of nascent Yugoslavia. Led by poet Ljubomir Micić, Zenitism was characterised by self-identification with the Balkans and an ambition to re-negotiate its Oriental and Balkan identity. ${ }^{3}$ The movement's primary platform was the Zenit journal, the first issue of which was published in Zagreb in February in 1921, before moving to Belgrade where it operated until the end of 1926. Having emerged within the post-War atmosphere, Zenit came into being as negative perceptions about the Balkans were beginning to harden. Many of these stereotypes fed upon the notion of 'balkanisation' as a process of violent geopolitical fragmentation, and 'Balkanism' as a discourse developed in political, diplomatic, journalistic, and creative practice that had evolved over two centuries through Western perceptions of the Ottoman Empire. It was, however, the violence of the Balkan Wars in 1912 and 1913 and the subsequent onset of World War I that gave specific form to ideas about the Balkans that persist today. Emerging from these conflicts, the Kingdom of Serbs, Croats and Slovenes united in 1918 as a region that had previously been under either AustroHungarian or Ottoman rule. Re-named the Kingdom of Yugoslavia in 1929, this was a federalist state that brought together a host of ethnicities and religions, with the aim of establishing a common political framework for Europe's Southern Slav population. In the West this socio-political maelstrom was perceived in negative terms. The noun „balkanisation“ and the verb „to balkanise“ were used, as Todorova points out, to refer not only to a ,parcelization of large and viable political units“ but also as ,, synonym for a reversion to the tribal, the backward, the primitive, the barbarian" (Todorova, 2009: 3). ${ }^{4}$ The region, which was now beyond Imperial borders had become the epitome of Europe's Other. As the first artistic and political movement that attempted to engage with and subvert this discourse, Zenitism faced a formidable challenge.

The goal of the movement, as set out in Zenit, was to invert the meaning of Balkan stereotypes by turning perceived shortcomings into strategic advantages, and establishing the Balkans as a youthful, pure, and innovative creative force. This ambition did not, however, stop there: the ultimate aim of Zenitism was nothing less that to

3 The movement was introduced in art history scholarship by Irina Subotić, Vida Golubović, and Ann Vasić, who re-discovered Zenit and left behind a seminal body of work on the movement. See Irina Subotić and Vida Golubović. 2008.Zenit 1921-1926. Belgrade: Narodna biblioteka Srbije; Irina Subotić, „Avant-Garde Tendencies in Yugoslavia,“ Art Journal 49, no. 1 (1990): 21-27; Irina Subotić and Ann Vasić, „Zenit' and Zenitism,“ The Journal of Decorative and Propaganda Arts 17, XIX-2 (2010): 565-579; Irina Subotić, „Zenitism/Futurism: Similarities and Differences,“ International Yearbook of Futurism Studies 1 (2011): 201-230.

4 See also Patrick Finney, ,,Raising Frankenstein: Great Britain, 'Balkanism' and the Search for a Balkan Locarno in the 1920s," European History Quarterly 33, No. 3 (2003): 317-342. 
„Balkanise Europe.“ Within the pages of the movement's journal, Micić discussed the subjugation of Yugoslavia in peace time by European authors, such as Lloyd George, Aristide Briand, Marshal Ferdinand Foch and Gabriele D'Annunzio, inviting his compatriots to reject the subservient position of sitting in ,the last row of European civilisation," and urging them to refuseto serve as ,blind and faithful watchdogs of foreign Western culture." (Zenit 24, May 1923: 1; Micić, Zenit 8, October 1921: 2-3). This ,stinking“ and ,pathological“ culture, Micić argued, no longer had anything to offer, as it was held down by decadence and decay of tradition, and its inability to free itself from this baggage to create something new (Micić, Zenit 38, February 1926: 3). Indeed, its moral bankruptcy had been demonstrated by the brutality of the First World War (Micić, Zenit 21, February 1923: 1) - from which Micić, who had served as an Austro-Hungarian soldier, had sustained lasting trauma that fuelled his political and artistic project. $^{5}$

The culture of the Balkans, by contrast, was unburdened by the weight of colonial and imperial history, and intellectual traditions that had produced the barbarity of the first global conflict. Thus instead of longing for a cultural traditions they did not have, and ultimately did not need, Balkanites were urged to embrace the absence of any real proprietary culture, and celebrate the polyphonic and fragmentary profile of the region. Belonging to the Balkans meant the ability to truly start from a tabula rasa - an opportunity that Western European avant-gardes could only ever dream of. Here in then lay a new vital, innovative and rebellious spirit that had the potential to rejuvenate the continent: to „Balkanise“ Europe would be to inverse the process of Europeanisation of the Balkans, through which this barbaric and unenlightened domain was to be brought into the fold of civilisation (Micić, Zenit 11, February 1922: 1). In the eyes of Zenitists, it was in fact Europe that needed transformation and cultural conquest.

Zenitist Balkanism was not only a protest against the prejudice and denigration to which the Balkan region had been subjected by the colonialist West; it was also a protest against the negative stereotype of the Slavic Orient in general. The inversion of the Europe-Balkan dynamic and direction of cultural influence also involved the inversion of the East-West dynamic, as illustrated by the graphics located in the upper margins of many issues of Zenit: "ИСТОК $\rightarrow$ ЗАПАД" or "ORIENT $\rightarrow$ OCCIDENT."

\footnotetext{
5 Micić reflects upon his own wartime experience in Ljubomir Micić, „Na rubu - Dragan Bublić,“ Zenit 1 (February 1921), 14-15. See also Igor Marjanović, „Zenit: Peripatetic Discourses of Ljubomir Micić and Branko Ve Poljanski," On the Very Edge, Modernism and Modernity in the Arts and Architecture of Interwar Serbia (1918-1941). ed. Jelena Bogdanović, Lilien Filipovitch Robinson, and Igor Marjanović. 2014. Leuven: Leuven University Press, 65-67; Zoran Markuš. 2003. Zenitizam. Beograd: Signature, 22.

6 The graphics appear in issues 8 (October 1921) to 15 (June 1922) inclusive.
} 


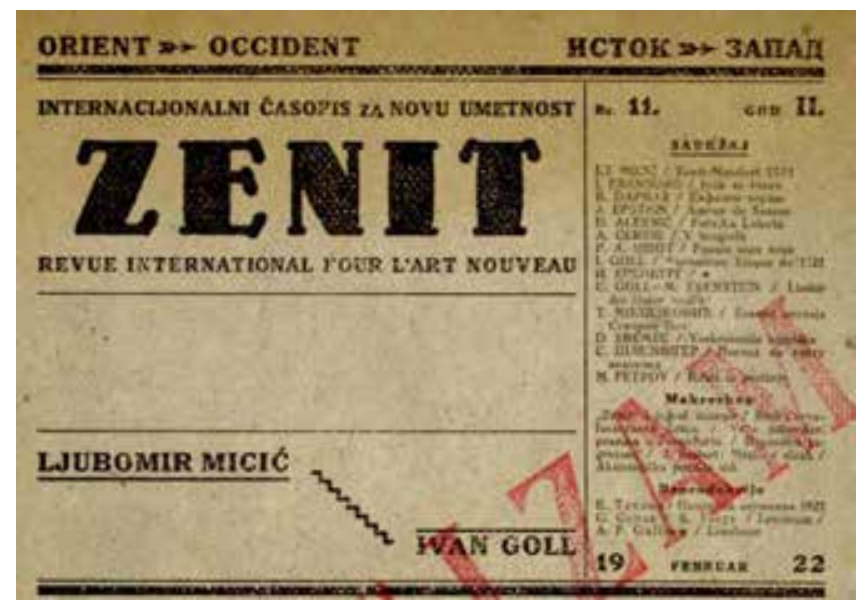

Figure 1. Zenit, cover page of issue 11, (February 1922)

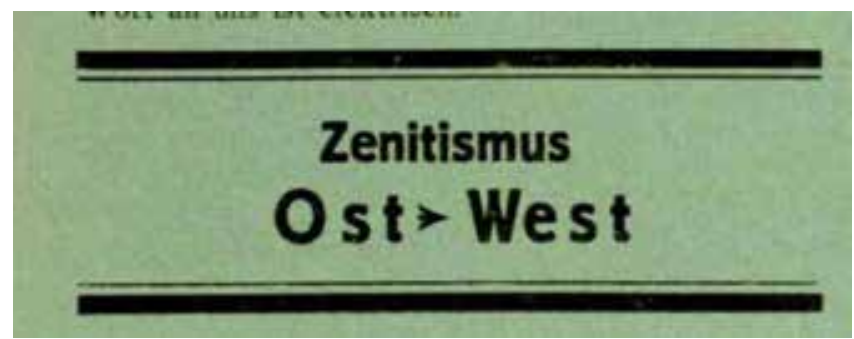

Figure 2. Zenit, page 9 of issue 8, (October 1921)

Situating the Balkans in the Orient involved associating Zenitism with Soviet Russia and communism as the vital force originating in the East. Zenitist association with revolutionary Russia began in the very first issue of Zenit, which included Micićs call for proletarians of the world to unite against the killing (of World War I), and the translation of a text by the Soviet Commissar of Enlightenment, Anatoly Lunacharsky (Micić, Zenit 1, February 1921: 1-2; Lunacharsky, Zenit 1, February 1921: 11-12 and Zenit 2, March 1921: 13-14). This engagement with political and cultural energy emanating from the East would take firm hold with the third issue,where Micic reproduced Aleksandar Blok's 1918 poem „Scythians“ on the front cover in its original Russian - a piece that rebelliously ascribes Oriental identity to Russia and the Slavic East. ${ }^{7}$ Blok's poem comes from a „barbarian lyre“:

7 The English translation of Blok's poem "Skify" is quoted from From the Ends to the Beginning, A Bilingual Anthology of Russian Verse hosted by Northwestern University, accessed on 14 March 2021. http://max.mmlc.northwestern.edu/mdenner/Demo/texts/scythians_blok.html. 
Yes, we are Scythians! Yes, we are Asians -

With slanted and greedy eyes!

$[\ldots]$

We, like obedient slaves,

Held up a shield between two enemy races -

The Tatars and Europe!

$[\ldots]$

But we are no longer your shield.

The mission to assert the supremacy of Balkan culture drew inspiration from the October Revolution and communism as a powerful alternative to the European political, economic, and cultural model. This connection would bereiterated throughout subsequent issues, with, for example, the image of Vladimir Tatlin's Monument to the Third International featured on the front page of issue 11 in February 1922. Wassily Kandinsky, Kazimir Malevich, Vladimir Mayakovsky, Lev Trotsky and Lunacharsky would all make appearances within the pages of Zenit, as the Orient was, both artistically and politically, to become the 'spectre haunting Europe' from the opening sentence of the Communist Manifesto. The political attraction of this subversion laid in its emancipatory potential, which held the prospect of overturning centuries-old hierarchies and asymmetries of power. This political shift simultaneously allowed for artistic liberation and a radical departure from tradition, a link that is captured in Micić's writing on Kandinsky, in which the Zenitist leader made a direct association between Kandinsky's pioneering break into pure abstraction and the artist's Russian heritage (Micić, Zenit 5, June 1921: 10-11). By the time the journal reached its final issue in December 1926, the link with revolutionary Russia had been fully articulated. Responding to the question „What is Zenitism?"“ and under the pseudonym „Dr Rasinov“" Micić would proclaim: „Zenitism is a child of Marxism [...] Teachings and aspirations spread by Marxism as a science, sociology, are the teachings that Zenitism spreads and revitalises in its own sphere of art" (Rasinov, Zenit 43, December 1926: 12).

Zenit was not, however, merely a mouthpiece of the communist East, and its intention was not simply to replace idolatry of the West with blind admiration for the East. Instead, its contributors drew upon the complexities of the Balkan condition, the fact that it was situated on the border between Europe and non-Europe, and often cast as the 'familiar Other.' Zenitism, that is, aimed to articulate and exploit the liminality of the Balkans. Thus rather than merely formulating an opposition to European culture, Zenitism approached Europe, like Blok's Scythians, as the enemy's land to be conquered- but this enemy was at the same time the main and coveted interlocutor. The inversion of the Europe-Balkan dynamics involved a sophisticated strategy that paired political and creative energy emanating from Russia with those tropes of the European avant-gardes that held potential for subverting the established order of relationships. 
This reordering is anticipated in Micićs description of Zenit as „The first Balkan journal in Europe and the first European journal in the Balkans" (Micić, Zenit 11, February 1922: 1). What did this meanin political and poetic terms? If the Russian Revolution provided inspiration that a different, more equal political reality was possible, the avant-garde provided the language for articulating a different conception of Europe, and the place of the Balkans within it. The main strategy of Zenitismwas to take the two central European stereotypes about the Balkans - that it was barbaric, and that it was divided in a chaotic manner - and demonstrate that these were in fact manifestations of a true avant-garde ethos. Zenitism asserts that it is the Balkan individual who can truly realise the aspirations of the European avant-garde, precisely because of her or his Balkan origins. Here the disordered, anarchic, polyphonic energy becomes an advantage rather than impediment, as it is through this authentic Balkan genius that the European avant-garde aspiration for a new and modern cultural landscape could be achieved.

Zenitism thus set out to align the negative stereotypes associated with the Balkans with the aesthetic principles of the European avant-garde. The movement's first step was to draw upon the nexus between notions of Balkan backwardness and primitivism and the Western-modernist 'primitive' as an ideal and a source of inspiration. The Balkan artist, properly belonging to a world that is barbaric, uncivilised, raw, uncultivated (as the discourse on Balkanism would have it) is closest to this ideal. Here Micić introduces the figure of the Barbarogenius, a resurrection of, ,Yugobalkanarchetype of HUMANHERO (ČOVEKHEROJ),“ who stands as an embodiment of raw Balkan creative energy, and is positioned through a series of texts in the journal as the authentic primitive (Micić, Zenit 10, December 1921: 11). The second step involved establishing a parallel between the notion of balkanisation as a form of geographic parcellation, which would always and only ever produce a frenzy of competing national and cultural units, and the emblematic internationality of the 1910s and 1920s avant-gardes, which existed as a series of intrinsically connected yet fiercely competitive groups.

The history of the notion of the primitive in Western art is laden with controversy and contradiction. It is the affirmation of the non-European cultural realm and involves, as many scholars have shown, ideas and practices intimately linked with colonialism. ${ }^{8}$ The obsession with the primitive was, in particular, the essential element of French modernism and avant-garde, with France epitomising Europe in the Zenitist discourse. ${ }^{9}$ The recourse to the so-called primitive, pre-civilisational condition had

8 For further information on the cultural and ideological underpinnings of this idea see Elazar Barkan and Ronald Bush, eds. 1995. Prehistories of the Future: Primitivist Project and the Culture of Modernism. Stanford: Stanford University Press; Carol Sweeney, 2004. From Fetish to Subject: Race, Modernism and Primitivism, 1919-1935. New York: Praeger Publishers; Marianna Torgovnick. 1991. Gone Primitive: Savage Intellect, Modern Lives. Chicago: University of Chicago Press.

9 See the manifesto „Delo Zenitizma“ (Zenit 8, October 1921, 2-3), in which Micić exclaims: „Panic/ 
originated in the sixteenth century, as the result of the 'discovery' of the New World. Beginning with the work of philosophers such as Michel de Montaigne, the archetype of a 'noble savage'would be idealised as expression of pure and honest existence, untouched by the corrupting influence of civilisation and its emphasis upon the idea of progress. Equally, this ideal was founded on the notion that non-European cultures can in general be characterised as barbarian or savage, and are located outside history (Boas, [1933] 1966). ${ }^{10}$ In the twentieth century, primitivism and modernism would converge in a new and powerful way, with primitivism recognised as a rejuvenating force that could push the then-fatigued European civilisation out of the doldrums, and infuse it with energy necessary to embrace modern industrial reality.

The two paradigmatic instances of primitivism in French modernist culture, routinely explored in arthistorical literature, are the paintings of Paul Gauguin in the Pacific 'New World,' and the performances of Josephine Baker. After leaving Europe in 1891 for what he would describe as „,bare and primordial Oceania,“ Gauguin called himself a barbarian and contrasted 'his'adoptive world to that of Western civilisation. As Nancy Perloff and numerous other art historians have demonstrated, however, Gauguin essentially projected European fantasies of decadence and sensuality in the primitive world onto a world of ,naturally naked“ Exoticised Eves, painted in poses from East Asian sources, and representing the Orient as a general concept of non-Western (Perloff, 1995). In his art, Gauguin does not empathise with the savage, but instead puts her on display in his paintings (which were produced for exhibition in Paris) in the manner that she would have been displayed in the Colonial Exhibit at the Great Exposition in Paris of 1889. Gauguin's 'barbarian' life, as Perloff uncovers, involved enjoying worldly comforts at a low cost, and having access to local women whom he used as models for his art, indulging both as artist and man.

The Zenitists understood that the type of engagement that European modern painters had made with the 'savage' was simply another form of perpetuating existing power asymmetries, and were conscious of avoiding a similar destiny for their own movement (Micić, Zenit, 10, December 1921: 11). Here perhaps the story of Josephine Baker provides a better model of how Zenitists imagined the 'savage' interaction.An African American performer from Harlem, Baker came to fame as a dancer in La revue nègre, an American show with an all-black cast which opened in 1925 at the Thêâtre des Champs Elysées in Paris (Babović, 2018: 142). In these and later performances at Folies PARIS IS BURNING/Fear/EUROPE IS DYING.“ The sense of opposition between East and West is articulated in the following manner: "A contemporary European is a dancer on a burning tight rope that is stretched between the Kremlin and the Eiffel Tower” (in Micić, „Delo“).

10 See also Brendan Frederick R. Edwards. 2008. "He Scarcely Resembles the Real Man”: images of the Indian in popular culture, accessed on 14 March 2021. http://digital.scaa.sk.ca/ourlegacy/exhibit_ popularculture 
Bergère, she appeared on stage naked, save perhaps for a feather, or the (in)famous skirt of artificial bananas used in her danse sauvage routine. ${ }^{11}$ She created a craze for the black body among white male bourgeois audiences, subjecting her nakedness to their gaze while at the same time entrancing and manipulating her audience and their expectations of 'savage' sexuality. As Anne Anlin Cheng points out, it is impossible to untangle where the appropriation of racial stereotypes stops and the artist's subversion of these begins, since Baker's dance, involving the focus on the surface (skin), the fascination with the primitive and the penchant for provocation actually exemplified modern notions of race, style, and artistic agency (Chang, 2013). Indeed, analysis of contemporary reactions to her performances reveals this split: while some saw Baker's art as a threat to black emancipation (as her dances conformed to and reinforced racial hierarchies), others recognised that her popularity had the potential to integrate black culture into the mainstream (Babović, 2018: 145-146). Importantly, her dancing and later film appearances were intimately tied to the French interwar colonial imagination, rather than the American discourse on race (Guterl, 2010: 26). ${ }^{12}$ As Matthew Pratt Guterl has shown, in a kind of pastiche she mimicked almost all genres of colonial representation of 'savage' colonial peoples, including the naked-breasted Orientalist stereotype of the harem girl, the Polynesian indigene, the seductress from the West Antilles, and the African tam-tam dancer, and offered herself up as ,an exemplar of everything outside of France, outside of the West, and outside of the modern metropole“ (Guterl, 2010: 26). Further complicating this dynamic, Baker was herself an apatride, belonging properly neither to Harlem nor to Paris but to the interwar international world of the Black Atlantic, in which in-betweenness created a vibrant counterculture, where fantasies of black art informed Europeans and European art shaped the expression of the blacks in a complex feedback loop. ${ }^{13}$

11 There are three memoirs, 20 biographies and countless numbers of scholarly articles on Baker. For an examination of the nature of her performances in the colonialist primitivist context see Elizabeth Ann Coffman, „Uncanny Performances in Colonial Narratives: Josephine Baker in Princess Tam Tam“, Paradoxa Vol. 3, No. 3-4, 1997. and Mae Henderson, "Josephine Baker and La Revue Nègre: From Ethnography to Performance", Text and Performance Quarterly Vol. 23 No 2 April 2003: 107-133. For an examination of the complex construction of self-representation in Baker's dance see Benetta JulesRosette. 2007. Josephine Baker in Art and Life: The Icon and the Image. Urbana: University of Illinois Press.

12 Matthew Pratt Guterl, “Josephine Baker's Colonial Pastiche”, Black Camera Vol. 1, No. 2 (Summer 2010): 25-37.

13 See Brent Hayes Edwards. 2003. The Practice of Diaspora: Literature, Translation, and the Rise of Black Internationalism. Cambridge, MA: Harvard University Press; Paul Gilroy. 1993. The Black Atlantic: Modernity and Double Consciousness. Cambridge, MA: Harvard University Press; Sieglinde Lemke. 1998. Primitivist Modernism: Black Culture and the Origins of Transatlantic Modernism. Oxford: Oxford University Press. 
As the „The first Balkan journal in Europe and the first European journal in the Balkans," Zenit straddled the two territories in a manner similar to how Josephine Baker's art straddled the trans-Atlantic territory between Blackness and Whiteness, simultaneously accepting and subverting Western Orientalist tropes originating in colonialist discourse. Micić, who had fought against Paris as a symbol of European decadence and colonialism and yet moved to live there after his Yugoslav Zenitist enterprise came to an end, both embraced the Western modernist notion of the 'primitive' and provided his own Balkan countercultural interpretation. In this way, Zenitism played with both positive and negative European notions of the primitive - as a source of new, external energy, but also a savage- a play whose ultimate aim was to provoke a repositioning and a redefinition of both Europe and the Balkans. „Zenitism wants to use Balkan creative primitivism to synthesize new art," writes Micić (Micić, Zenit 11, February 1922: 2). „We are naked and innocent,“ he proclaims, presenting themselves in the image of primitive naiveté (Micić, Zenit 8, October 1921: 4). In his essay „Barbarism as Culture," Risto Ratković describes Balkan barbarism by stating that:

We are not thinking of barbarism as culture's antipode, but of barbarism as culture, as the healing of culture. Such barbarism is the inexhaustible and eternally rejuvenating injection of purity, the perennial disinfection of rotten spaces and the electrolysis of stale spirit (Ratković, Zenit 37, NovemberDecember 1925, 9).

In parallel, Zenitists invoke the Western fear of the Orient as dangerous, born in the colonialist discourse but, in the age of Zenit, most potently invoked by the rise of communism in the Slavic East. The Barbarogenius furthermore is an embodiment of the aesthetic trope of the primitive who, as a Balkanite, is also dangerous. „We will drown the eyes of your weeping ideas, “Micić threatens. „We will fry the brains of genius on the fires of our gaze. [...] The Barbarogenius is coming" (Micić, Zenit 36, October 1925: 14). The Barbarogenius has a predilection for „infinite vindictive hatred,“ and is ready to commit an ,act of unprecedented savagery - to Balkanise Europe!“(Micić, Zenit 13, April 1922: 18).

The originality of Zenitism lay in how it played with the polyvalence of the East as both a source of aesthetic inspiration, but also fear - two notions bound around the Western fascination with the exotic Orient. Indeed, Zenitism was not only about the Balkans, but the Orient in general. Similar to Baker's pastiche, in which she as a Black American impersonated, in different guises, almost every French colonial stereotype, Zenitism (especially towards the end of the movement) presents the Barbarogenius as the incarnation of an entire series of controversial entities - as the racial and political Other of bourgeois Europe. While Zenitists identified with the paradigmatic Balkanist 
trope of the Vampire (Micić, Zenit 36, October 1925: 14), the Barbarogenius was, throughout the course of Zenit's publication, identified with a plethora of problematic entities: the Serbs, the Blacks, Lucifer, the Indians, the fictional Anarch Hunger, and the proletarians. ${ }^{14}$ The Barbarogenius was not only Balkan, and not only Oriental, but a quintessential, basic Other.

The second alignment between Balkan stereotypes and avant-garde aesthetics exploited by Zenitists was the parallel between the notion of balkanisation, and the avant-garde aesthetics of internationalism and transnationalism. Todorova establishes balkanisation as a phenomenon ostensibly exemplifying a lack of cultural coherence, as small political units left in the wake of the disintegration of European empires made order and togetherness impossible, creating a space of historic disjuncture and aggression. Just as this notion of balkanisation solidified, the European and transatlantic avant-gardes created a cultural terrain that was also marked by simultaneous attempts at unity and competition between national movements. ${ }^{15}$

Zenit's form reflects both the cacophonic condition of the avant-garde by presenting it as a 'balkanised' realm, for the first time drawing together and juxtaposing alphabets, languages, and aesthetic principles, manifesting the coexistence of heterogeneous and sometimes incompatible idioms as both an artform and a type of cultural politics. Zenit was organised as the common territory of different 'tribes' the Expressionists, the Dadaists, the Futurists, the Constructivists, the Suprematists, Proletkult, the Poetists, the Purists, the Bauhaus. The pages of the journal carried the work of Filippo Tommaso Marinetti, Lajos Kassák, Wassily Kandinsky, Kazimir Malevich, Theo van Doesburg, Aleksandr Blok, Sergei Esenin, Vladimir Mayakovsky, Jaroslav Seifert, Peter Behrens, Walter Gropius, Geo Milev, Anatoly Lunacharsky and Lev Trotsky, alongside pieces by local contributors such as Branko Ve Poljanski, Dragan Aleksić and Boško Tokin. Though primarily published in Serbo-Croatian, the journal also included contributions in English, Russian, Italian, Czech, German, Swedish, Hungarian, Bulgarian, Flemish, Esperanto and French. Zenitism demonstrated the 'balkanicity' of avant-garde Europe, the simultaneous coexistence, in one realm, of similar yet embattled factions speaking different languages and advocating different political and cultural trajectories. By engaging with and interpreting the tropes of primitivism and modernist fragmentation from the Balkan perspective, Zenitism positioned itself (and its region) as a quintessentially modern and European vision.

14 The character of Anarch Hunger was introduced in Zenit 40 (April 1926).

15 See Hubert van den Berg and Lidia Głuchowska, ed. 2013. Transnationality, internationalism and nationhood: European avant-garde in the first half of the twentieth century. Leuven and Walpole: Peeters. 
In April 1929, Josephine Baker visited Belgrade while in the midst of an international tour (Babović, 2018: 140-173). According to Jovana Babović, Baker's „seven-day sojourn in the Yugoslav capital yielded almost nothing but glowing media coverage“" (Babović, 2018: 141). While her visits to other European cities regularly provoked protests, riots, and at times physical violence, Belgraders were apparently smitten by the „black star“ (Babović, 2018: 140). On the one hand she was seen as an embodiment of the latest fashion coming from Paris, which was perceived as the epicentre of civilisation. Yet Baker was herself quite different to the popular stereotypes of refined French culture, and exhibited palpable enthusiasm for the culture of her hosts - including an appetite for the local cuisine (Babović, 2018: 155). Whatever the reason for her unwavering popularity in the Yugoslav capital, among Belgraders Baker successfully straddled an otherwise significant cultural divide: she was recognised and embraced as both French and not-French. Could Zenitsts have hoped for similar success in being acknowledged as both Balkan and European?

The international recognition of Zenitism as an authentic avant-garde has been well documented. ${ }^{16}$ The movement succeeded in its effort to both exploit and invert Balkanist stereotypes and enter the European cultural domain on its own terms. Yet the ambition of Zenitism went further still, and its true originality lies in having recognised that the challenge extended beyond shifting away from performing the Orient or representing the Orient for the West, and in fact creating appeal for Balkan identity among the Balkan populations themselves, and renegotiating the presence of Orientalist stereotypes among the Balkanites.

The Zenit journal sought to address its local audience by offering key manifesto es in both the Cyrillic and Latin versions of Serbo-Croatian, and challenge not only the broader colonialist rhetoric, but also what Alexander Kiossev would describe as the „self-colonisation“ of the Yugoslav peoples (Kiossev, 1999).The essence of this self-colonisation was cultural mimicry, being an attempt to imitate (and thereby be acknowledged by) the West. Slovenes, Croats, Vojvodinians and Bosnians were most heavily influenced by the culture of the former Austro-Hungarian empire (Vienna, Budapest, Munich and Berlin), while Serbs more readily turned towards Britain and France.Thus, as Yugoslavia absorbed European values through education, political

16 Irina Subotić and Vida Golubović brought Zenit to public attention in the 1980s by writing the first and most substantive texts on the journal, and stressing its importance in the West by arguing in favour of Zenit's inclusion into the Yugoslav artistic cannon. In their most important works, Zenit $i$ avangarde 20-ih godina (1983) and the more recent monograph Zenit 1921-1926 (2008), they embrace Micić's own rhetoric about his European fame that accompanied his local failure. In Modern Architecture in Eastern Europe: From the Baltic to the Balkans, c. 1890-1939 (1999), S. A. Mansbach notes that „Zenit was a full partner in the international avant-garde" and emphasises Micić's collaboration with German, Italian, and Russian avant-garde movements. 
discourse, and cultural consumption, internal divisions were amplified by the adoption and perpetuation of Western ideology.

Zenitists thus took specific aim at what Bakić-Hayden has described as „nesting orientalisms“ which were most prominent in those areas of Yugoslavia that had previously been part of the Austro-Hungarian Empire (Bakić-Hayden, 1995). In fact, each Yugoslav nation would transpose the East-West dichotomy of the European model onto itself, venerating places that were positioned further West for their ostensible cultural superiority, and looking upon its neighbours as „Oriental“ in order to establish distance from the non-European Yugoslavs, and in particular those who had once been under Ottoman rule. ${ }^{17}$ Yet of course- then as today, as Močnik points out in respect of Slovenia - the "definitive indication" that a country belongs to the Balkans is that it is obsessed with the opposition between Europe and non-Europe; with the association of the „Balkans“ and non-Europe; and with using the Balkans as a perpetual and ideological Other (Močnik, 2003: 100).

It is therefore unsurprising that, while they were recognised by their international peers, Zenitists ultimately failed to capture and inspire an audience in Yugoslavia. In the movement's first phase, Zenitists failed to provoke any self-evaluation among the Croatian elites; having failed in Zagreb, Micić moved the journal to Belgrade in the belief that Zenitism might prosper in the capital. Yet the situation in Belgrade was no different. In his 1925 essay „Thank You Beautiful Serbia,“ Micić would lament „bitter Serbia," which had ultimately crushed all of his dreams with her "oily fist," as he found the local population unreceptive to the Zenitist project, and the local authorities openly hostile (Micić, Zenit 36, October 1925: 2-4 ) ${ }^{18}$ Belgraders were feigning sophistication in the same way the citizens of Zagreb had; they would, as Micić bemoaned, admire any „European parvenu“ who came to what was ,the last European colony.“

Reflecting on the Zenitist project a century on from the publication of the first issue of its journal, there is no doubt that the movement contributed to an acknowledgement that, as one historian has put it, „East European stories are at the core of European history" (Babović, 2018: 11). Zenitism not only challenged cultural hierarchies and positioned itself as a constituent part of the history of the European avant-garde, but also invited audiences to escape the practice of ,nesting orientalisms.“

17 See also Todorova on Bakić-Hayden's use of the term „nesting orientalisms, “ in Todorova, Imagining the Balkans, 58. For a discussion of the problem of ,nesting balkanisms“ in post-1990s Serbian and Croatian society see Stefaan Jansen, „Svakodnevni orijentalizam: Doživljaj 'Balkana'/'Evrope' u Beogradu i Zagrebu,“ Filozofija i društvo (Journal of the Belgrade Institute for Social Research and Philosophy) XVIII (2002): 33-71.

18 On the persecution and closing of Zenit see Iva Glisic and Tijana Vujosevic, „I Am Barbarogenius: Yugoslav Zenitism of the 1920s and the Limits of Performativity," Slavic and East European Journal 60:4 (2016): 718-743. 
In this way, Zenitism opened up a conversation that has lost none of its relevance. By embracing Balkan identity as a method of emancipating the Balkan subject in a process described by Andrej Grubačić as „Balkanization from below,“ Zenitists demonstrated that they did not belong to the Balkans, as they did not subscribe to the Balkan/ Europe dichotomy, and did not see the world as divided between the Orient and the Occident, or Europe and non-Europe (Grubačić, 2012). Alongside its attempt to incite countercultural self-re-Orientalisation, the Zenitist enterprise is today recognised for its peculiar melange of Oriental and Occidental identity, and its aspiration to belong at once to both the Slavic Orient and Western Europe. It is this quest for dual identity that lends the movement its sophistication and provocative complexity. The Europeanness of the Barbarogenius is not, ultimately, a betrayal of the Balkans, but in fact represents a way to progress beyond an otherwise debilitating predicament - albeit only through the destruction of the hegemonic opposition between Europe and its various Others.

\section{REFERENCES:}

1. Babović, Jovana. 2018. Metropolitan Belgrade, Culture and Class in Interwar Yugoslavia. Pittsburgh: University of Pittsburgh Press.

2. Bakić-Hayden, Milica and Robert Hayden. 1992. „Orientalist Variations on the Theme 'Balkan': Symbolic Geography in Recent Yugoslav Cultural Politics.“ Slavic Review 51, No. 1 (1992): 1-15.

3. Bakić-Hayden, Milica. „Nesting Orientalisms: The Case of Former Yugoslavia.“ Slavic Review 54, No. 4 (1995): 917-931.

4. Bakić-Hayden, Milica. 2006. Varijacije na temu 'Balkan'. Beograd: Institut za filozofiju i društvenu teoriju I. P. Filip Višnjić.

5. Bjelić, Dušan I. and Obrad Savić, eds. 2003. Balkan kao metafora: Između globalizacije $i$ fragmentacije. Beograd: Beogradski krug.

6. Boas, George ([1933] 1966). The Happy Beast in French Thought in the Seventeenth Century. Baltimore: Johns Hopkins Press. Reprinted by Octagon Press in 1966.

7. Chang, Anne Anlin. 2013. Second Skin: Josephine Baker and the Modern Surface. Oxford: Oxford University Press.

8. Dix, Hywel. 2015.,,On Balkanism and Orientalism: Undifferentiated Patters of Perception in Literary and Critical Representation of Eastern Europe.“ Textual Practice 29, No. 5 (2015): 973-991

9. Fleming, Katheryne. 2000. „Orientalism, the Balkans, and Balkan Historiography.“ The American Historical Review 105, No. 4 (2000): 1218-1233.

10. Grubačić, Andrej. 2012.,,Balkanization of Politics, Politics of Balkanization.“ Globalizations 9, №. 3 (2012): 439-449.

11. Guterl, Matthew Pratt. „Josephine Baker’s Colonial Pastiche.“ Black Camera 1, No. 2 (2010): 25-37

12. Hammond, Andrew. 2004.,The Uses of Balkanism: Representation and Power in British 


\section{ZENIT I ZENITIZAM / ZENIT AND ZENITISM}

Travel Writing, 1850-1914.“ The Slavonic and East European Review 82, No. 3 (2004): 601624.

13. Hammond, Andrew. 2007. „Typologies of the East: On Distinguishing Balkanism and Orientalism.“ Nineteenth-Century Contexts: An Interdisciplinary Journal 29, No. 2-3 (2007): 201-218.

14. Kiossev, Alexander. „Notes on Self-Colonizing Cultures.“ In: Bojana Pejić and David Elliott eds. 1999. After the Wall: Art and Culture in Post-Communist Europe. Stockholm: Moderna Museet. 114-118.

15. Kølsto, Pal. 2016. „Western Balkans as New Balkans: Regional Names as Tools for Stigmatization and Exclusion." Europe-Asia Studies 68, No. 7 (2016): 1245-1263

16. Lunacharsky, Anatoly. 1921. „Proletkult.“ Zenit 1 (February 1921), 11-12 and Zenit 2 (March 1921), 13-14

17. Micić, Ljubomir. 1921. „Čovek i Umetnost.“Zenit 1 (February 1921), 1-2

18. Micić, Ljubomir. 1921. „Makroskop.“ Zenit 5 (June 1921), 10-11

19. Micić, Ljubomir. 1921. „Delo zenitizma.“ Zenit 8 (October 1921), 2-3

20. Micić, Ljubomir. 1921.,Savremeno novo i slućeno slikarstvo.“ Zenit 10 (December 1921), 11

21. Micić, Ljubomir. 1922. „Zenit-Manifest.“ Zenit 11 (February 1922), 1

22. Micić, Ljubomir. 1922. „Kategorički imperativ zenitističke pesničke škole,“ Zenit 13 (April 1922), 17-19

23. Micić, Ljubomir. 1923.,Zenitizam kao balkanski totalizator novog života i nove umetnosti.“ Zenit 21 (February 1923), 1-2

24. Micić, Ljubomir. 1925. „Varvarsku kajganu.“ [Barbarian Omelette] Zenit 36 (October 1925), 14

25. Micić, Ljubomir. 1925. „Hvala ti Srbijo lepa,“Zenit 36 (October 1925), 2-4

26. Micić, Ljubomir. 1926. „Manifest varvarima duha i misli na svim kontinentima.“ Zenit 38 (February 1926), 2-4

27. Močnik, Rastko. 2003. „Balkan kao element u ideoloskim mehanizmima.“ In: Bjelić, Dušan I. and Obrad Savić, (eds.). 2003. Balkan kao metafora: između globalizacije i fragmentacije. Beograd: Beogradski krug. 98-137

28. Perloff, Nancy. 1995. „Gauguin's French Baggage: Decadence and Colonialism in Tahiti.“ In: Elazar Barkan and Ronald Bush (eds.). 1995. Prehistories of the Future: Primitivist Project and the Culture of Modernism. Stanford: Stanford University Press.

29. Rasinov, Dr M. „Zenitizam kroz prizmu marksizma. “ [Zenitism through the Prism of Marxism] Zenit 43 (December 1926), 12

30. Ratković, Risto. 1925.,,Barbarstvo.“Zenit 37 (November-December 1925), 9-10

31. Said, Edward W. 1978. Orientalism. London: Routledge and Kegan Paul Ltd.

32. Todorova, Maria. 1997 [here 2009]. Imagining the Balkans. Oxford: Oxford University Press.

33. Zenit 24 (May 1923), 1 


\section{Zenitizam i orijentalizam}

Apstrakt: Osvrćući se na stogodišnjicu začetka zenitizma, ovaj esej ispituje kako se pokret bavio stereotipima o slovenskom Orijentu, a posebno diskursom o balkanizmu. Evropsko orijentalističko čitanje Balkana postalo je naročito temeljno u godinama oko Prvog svetskog rata. U nastojanju da izokrenu karakteristike koje degradiraju Balkansko poluostrvo, zenitisti će krenuti u misiju „Balkanizovati Evropu“, predstavljajući umetnika s Istoka kao podmlađivačku, revolucionarnu silu koja izranja iz kulturne tabule rase. Zenitizam je nastojao da destabilizuje dominantni orijentalnozapadni diskurs uspostavljanjem paralela između postojećih negativnih stereotipa na Balkanu i estetskih tropova evropske avangarde. Konkretno, zenitisti su uspostavili balkanskog „barbarogenija“ kao arhetipskog modernističkog varvarina - upravo lik koji je evropska inteligencija dočarala kao spasitelja svog bezvoljnog modernog stanja. Pored toga, zenitistički pokret je uspostavio analogiju između fragmentacije obeležja Balkana i kulturne kakofonije avangarde. Autorke tvrde da političke i estetske strategije pokreta imaju zapanjujuću sličnost s crnim Atlantikom i njegovom „međupojasnošću“ - ambicijom da odoli dvama suprotstavljenim svetovima. Nastao oko istoimenog časopisa Zenit, koji je zamišljen kao „prvi balkanski časopis u Evropi i prvi evropski časopis na Balkanu“, zenitizam je primenjivao evropske avangardne estetske strategije, istovremeno odbijajući evropske pretenzije na kulturnu nadmoć. Za jugoslovensku, sovjetsku i zapadnoevropsku publiku, časopis je imao dva paralelna cilja: kreativno „balkanizovanje“ Evrope i predanost demontiranju jugoslovenskih „odomaćenih orijentalizama" borbom protiv reprodukcije negativnih stereotipa među stanovnicima regije. U pozadini evropske krize i globalne potražnje za obnovljenom emancipatorskom borbom, ambicija zenitizma danas je veoma dopadljiva.

Ključne reči: avangarda, zenitizam, Jugoslavija, orijentalizam, balkanizam. 